\title{
Methodology to Identify SMEs Needs of Internationalised and Collaborative Networks
}

\author{
Beatriz Andrés and Raúl Poler \\ Research Centre on Production Management and Engineering (CIGIP), \\ Universitat Politècnica de València (UPV) \\ Plaza Ferrándiz y Carbonell, 2, 03801 Alcoy, Spain \\ \{beaanna, rpoler\} @cigip.upv.es
}

\begin{abstract}
This paper provides a methodology to support researchers in the identification of SMEs needs encountered when establishing collaborative processes within non-hierarchical manufacturing networks. Furthermore, the methodology also determines the needs when non-hierarchical networks internationalise their processes and operations to overcome globalisation and competitive environments. The major goal of this study is to provide a methodology to enable researchers to underline factors of SMEs integration with particular emphasis on the internationalisation of operations and the establishment of collaborative processes with networked partners. The provided methodology is the first step to develop a future empirical study to explore the findings of the literature review applied to SMEs and to identify the enterprises needs appeared when internationalised and collaborative processes are established in nonhierarchical networks.
\end{abstract}

Keywords: SMEs, non-hierarchical networks, internationalisation of operations, collaborative needs.

\section{Introduction}

The nature of the modus operandi in small and medium enterprises (SMEs) is changing by means of partnerships with other companies in complex value chains now globally extended [1]. Firms' competitiveness has experienced several changes over the last years. This tendency changes the way how SMEs work and relate [1]. As a result, the Non-Hierarchical manufacturing Networks (NHN) concept has emerged implying a decentralised decision making perspective and commitment of all companies without losing their authority in decision-making.

Competitive and global environments have also allowed changing the way how SMEs operate within a network through the internationalisation. Globalisation forces that the operations network design must encompass multiple regions that are becoming more widespread, forcing networks to cope with greater complexity [2]. Internationalisation is defined as the creation and management of production facilities in foreign countries to benefit from tariff preferences, lower labour costs, subsidies and lower logistics costs, as consequence a common approach to internationalisation aims 
to reduce costs and increase competitiveness in the short term [3]. Nowadays, companies are more internationalised due to the extension of the value chain configurations beyond national borders. Nevertheless, the internationalisation starting up process is a difficult decision to make, because it implies risks especially for SMEs whose capabilities and resources are insufficient. Many SMEs fail in foreign markets due to the production management of internationalised networks requires a greater collaboration to achieve optimal degrees of quality, flexibility and costs [4].

Regarding the networks under study (NHN), the evolution from a traditional hierarchical network, based on centralised decision making, to a NHN implies that SMEs have to face new challenges. The literature review carried out by [5] identifies and structures the emerging needs of SMEs that decide to establish collaborative relationships in a NHN. Besides, if SMEs establish in their strategy the internationalisation of operations, collaborative problems SMEs have to face are increased within the NHN. Consequently internationalisation in NHN enlarges collaborative problems that SMEs have to face within a network; therefore, problems arising from the internationalisation must be added to those existing in the establishment of collaborative processes already defined by [5-6]. In the light of this, a number of needs must be identified and subsequently addressed regarding (i) the establishment of collaborative relationships amongst NHN partners characterised by decentralised decision making and (ii) the internationalisation of operations.

Considering the reasons above stated a generic methodology to identify the SMEs obstacles to overcome when establishing collaborative relationships among national and international partners is provided in order to structure the SMEs needs that appear when they decide to participate in collaborative and international manufacturing networks. The proposed methodology allows sequencing the actions to be taken in order to identify the weaknesses that can appear in SMEs when they decide to belong to an internationalised and collaborative NHN. Taking into account the literature review developed by [5], it can be said that there is an absence of a unified approach to assist the process identification of needs for international and collaborative networks. Therefore, this paper develops a methodology in order to fill this identified gap.

\section{Methodology Background}

This section provides the methodology background based on a questionnaire to allow SMEs identifying the needs they find when establishing collaborative relationships. Regarding the methodology, two levels are considered (i) network level that consists of all nodes in the NHN and (ii) local level that consists of each SME [7]. The methodology takes into account the local SME level comparing with needed requirements at network level. Participating SMEs must identify in which processes are involved within the NHN and the roles and responsibilities they assume.

SMEs adopting internationalised processes establish relationships with SMEs with limited number of responsibilities, decision making, participation in network 
operations and resources. From the collaborative NHN point of view, participating SMEs have higher expectations in their foreign SMEs and, therefore, try to get a lot more of them. Thus, internationalisation of operations in a collaborative perspective does not only reduces costs advantages, but also provide access to a global production and distribution network closer to potential markets, with easy access to customers, suppliers, or workers with specific skills. In collaborative NHN partners have greater management capacity and autonomy in decision making than just operational management of production, including: product and process development, decision making in procurement and purchasing, technical support, etc. [8]. The evolution of a SME from an isolated perspective to an integrated perspective within a collaborative NHN, benefits synergies between enterprises, reduce costs, increase reliability of delivery and reduce the learning curve of other members of the network operations [9]. The internationalisation process within collaborative NHN is a difficult decision making due to consists of wide range of SMEs. In the light of this, this paper allows to identify limited resources and capabilities of SMEs when they decide to establish the internationalisation of operations in collaborative NHN.

In the provided methodology, the weaknesses that can be identified in networked SMEs are clasified through a 4-dimensions analysis: (i) strategy, (ii) technology, (iii) partners and (iv) product (Fig.1). This 4-dimensions are considered taking into account the PEST factors analysis (Political, Economic, Social and Technological) as the identification of the overall environmental factors that affect companies [10]. All dimensions are related and linked to each other and establish the most important pillars to identify the SMEs needs. The analysis is performed in parallel for the two identified levels: (i) the environment that characterizes the collaborative NHN based on internationalisation of operations and (ii) the specific context of SMEs, regarding SMEs features and capabilities to cope with collaborative NHN requirements (Fig.1).

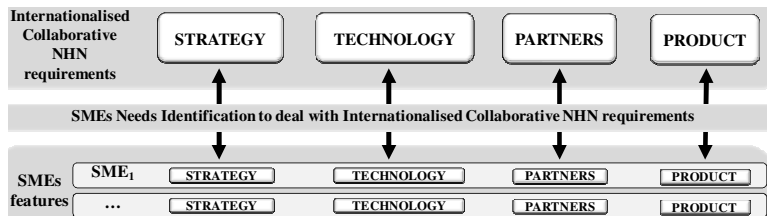

Fig. 1. 4-Dimension Analysis at Network and Local level

The SMEs environment (external view) characterises the collaborative environment within the network they belong to: (i) Strategy Dimension: decisions are based in network design, decision making system, strategies and Performance Management System (PMS) design, (ii) Technology Dimension: decisions are related with needed technologies and systems to address the exchange of information and knowledge, process connection, interoperability and security systems for exchanging information, 
(iii) Partners Dimension: treats about coordination, contract negotiation, sharing costs and benefits, relationships with partners through collaborative arrangements, orders management and alignment of strategies and (iv)Products Dimension: decisions are aimed at establish collaborative forecast, planning and replenishment, production scheduling, inventory management and product design.

The specific context (internal view), characterises the SMEs features: (i) Strategy Dimension: takes into account the SME location strategy, decision-making system, performance management, degree of strategy alignment with the global network strategy, (ii) Technology Dimension: identify the SME capability for technological and scientific innovation, technological innovation infrastructure, scientific and technological knowledge level, (iii) Partners Dimension: analyse the SMEs capability and bargaining power, trust, risk, equity, uncertainty, participation in company, profits, collaborative relationships with partners and threats of vertical integration forward or backward and (iv) Product Dimension: deal with SMEs acceptance of sharing product information, product storage and product importance for the NHN.

\section{Methodology}

A methodology to identify the degree of adaptation with SMEs partners that belong to collaborative NHN is provided in this section (Fig. 2). Through the degree of adaptation SMEs can identify the problems they have to overcome to fulfil the internationalised collaborative NHN requirements. Therefore, the methodology allows networked partners to determine the adaptability between the two scenarios: local characteristics (SME) and network requirements (NHN) when establishing internationalisation of operations. The methodology sequence allows to consider first of all if the SME is willing to participate in a collaborative NHN and to internationalise his operations. Once the mission and vision from the network is defined the methodology starts working with the internal and external analysis that will allow experts to define the degree of adaptation of the SME for each requirement at network level. Finally, through the degree of adaptation, specialists will be able to identify the SMEs needs and weaknesses in order to be overcame and enable SMEs to be ready to start collaborative relationships in international NHN.

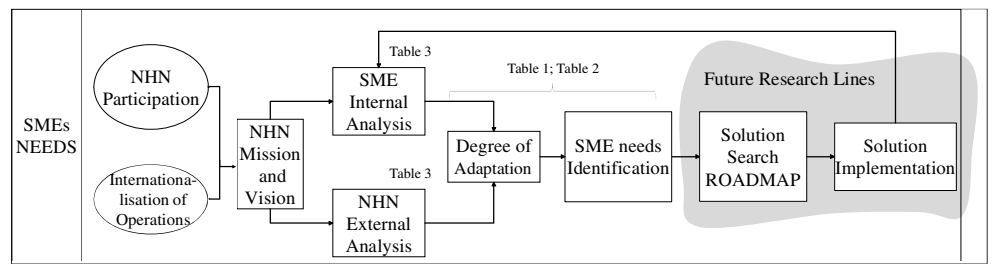

Fig. 2. Methodology Scheme to identify the SMEs needs 
Table 2 allows identifying the degree of adaptation and the emerging needs of SMEs in establishing collaborative relationships in NHN. The Degree of Adaptation represented in the Table 1 scales via 1 to 10 , how the SMEs features fit into the needs of the collaborative NHN. Questionnaire provided in Table 3 allow the SMEs to easily identify the appropriateness and the SMEs degree of adaptation regarding the requirements of the internationalised collaborative NHN. The questions enable SMEs to identify the degree of adaptation in Table 2 and; therefore, the problem to overcome. Thus, each numbered question $\left(Q_{x}\right)$ is associated to each problem and allows experts to determine the degree of adaptation of each SME in relation to collaborative NHN needs (Table 2).

Table 1. Degree of Adaptation Legend

\begin{tabular}{cll}
$\begin{array}{c}\text { Degree of } \\
\text { Adaptation }\end{array}$ & Definition & Explanation \\
\hline 0 & Very Weak & $\begin{array}{l}\text { The SME does not have capabilities and resources to belong to } \\
\text { a collaborative NHN }\end{array}$ \\
\hline 1 & Weak & $\begin{array}{l}\text { The SME capabilities and resources do not favour the } \\
\text { collaborative NHN requirements }\end{array}$ \\
\hline 3 & Moderate & $\begin{array}{l}\text { The SME capabilities and resources slightly favour the } \\
\text { collaborative NHN requirements }\end{array}$ \\
\hline 5 & Good & $\begin{array}{l}\text { The SME capabilities and resources favour the collaborative } \\
\text { NHN requirements }\end{array}$ \\
\hline 7 & High & $\begin{array}{l}\text { The SME capabilities and resources of tightly fit with the } \\
\text { requirements of the collaborative NHN }\end{array}$ \\
\hline 9 & Very High & $\begin{array}{l}\text { The SME capabilities and resources are equal to the } \\
\text { requirements needed within the collaborative NHN } \\
2,4,6,8 \text { are mediate values }\end{array}$ \\
\hline \multicolumn{7}{c}{} \\
\hline
\end{tabular}

Table 2. Degree of Adaptation to identify SMEs needs based on 4-Dimensional Analysis (S: Strategic, T: Tactical, O: Operational)

\begin{tabular}{|c|c|c|c|c|c|}
\hline & $\begin{array}{l}\text { Collaborative } \\
\text { NHN }\end{array}$ & $\begin{array}{c}\text { Adaptation } \\
\text { Degree }\end{array}$ & SME & $\begin{array}{r}\text { PROBLEM TO } \\
\text { TACKLE }\end{array}$ & LEVEL \\
\hline \multirow{8}{*}{ 窇 } & Network Design & $Q: 1$ & SME location & Network Design & $\mathrm{S}$ \\
\hline & \multirow{4}{*}{ Strategy } & \multirow{3}{*}{$Q: 2$} & Alignment Degree & \multirow{3}{*}{$\begin{array}{r}\text { Strategy } \\
\text { Alignment }\end{array}$} & \multirow{3}{*}{ S } \\
\hline & & & SME Objectives & & \\
\hline & & & Market Position & & \\
\hline & & $Q: 3$ & $\begin{array}{l}\text { Participation in other } \\
\text { Networks }\end{array}$ & $\begin{array}{r}\text { Partner } \\
\text { Selection }\end{array}$ & $S$ \\
\hline & $\begin{array}{l}\text { Decentralised } \\
\text { Decision Making }\end{array}$ & $Q: 4$ & Decision System Making & $\begin{array}{r}\text { Decision System } \\
\text { Design } \\
\end{array}$ & $S$ \\
\hline & \multirow{2}{*}{ PMS collaborative KPIs } & \multirow{2}{*}{$Q: 5$} & SME PMS & \multirow{2}{*}{ PMS Design } & \multirow{2}{*}{$\mathrm{S}$} \\
\hline & & & KPIs & & \\
\hline \multirow{6}{*}{ 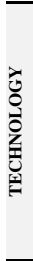 } & \multirow{4}{*}{$\begin{array}{l}\text { Technologies to } \\
\text { address the } \\
\text { collaborative } \\
\text { exchange of } \\
\text { information and knowledge }\end{array}$} & \multirow{4}{*}{$Q: 6$} & $\begin{array}{l}\text { Capability for technological } \\
\text { and scientific } \\
\text { innovation }\end{array}$ & \multirow{2}{*}{$\begin{array}{r}\text { Information } \\
\text { Exchange }\end{array}$} & \multirow[t]{2}{*}{$\mathrm{O}$} \\
\hline & & & $\begin{array}{lll}\begin{array}{l}\text { Level of } \\
\text { sophistication }\end{array} & \text { technical } \\
\end{array}$ & & \\
\hline & & & \multirow{2}{*}{$\begin{array}{l}\text { Level of scientific and } \\
\text { technological knowledge }\end{array}$} & $\begin{array}{r}\text { Knowledge } \\
\text { Management }\end{array}$ & \multirow{2}{*}{$\mathrm{T}$} \\
\hline & & & & $\begin{array}{r}\text { Uncertainty } \\
\text { Management }\end{array}$ & \\
\hline & Process Connexion & $Q: 7$ & \multirow{2}{*}{$\begin{array}{l}\text { Technology } \\
\text { Innovation } \\
\text { Infrastructures }\end{array}$} & $\begin{array}{r}\text { Process } \\
\text { Connexion }\end{array}$ & $\mathrm{O}$ \\
\hline & Interoperability & $Q: 8$ & & Interoperability & $\mathrm{O}$ \\
\hline \multirow{7}{*}{ 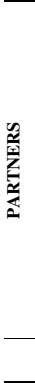 } & \multirow{2}{*}{ Strategy Alignment } & \multirow{2}{*}{$Q: 9$} & SME Strategy & $\begin{array}{r}\text { Partners } \\
\text { Collaboration } \\
\end{array}$ & $\mathrm{S}$ \\
\hline & & & $\begin{array}{l}\text { Vertical } \\
\text { Integration Threat }\end{array}$ & $\begin{array}{r}\text { Partners } \\
\text { Selection }\end{array}$ & $\mathrm{S}$ \\
\hline & Contracts Negotiation & $Q: 10$ & $\begin{array}{l}\text { Capacity and } \\
\text { Power Negotiation }\end{array}$ & $\begin{array}{r}\text { Contracts } \\
\text { Negotiation }\end{array}$ & $\mathrm{T}$ \\
\hline & $\begin{array}{l}\text { Share costs and benefits } \\
\text { Equity } \\
\text { Partners Involvement }\end{array}$ & $Q: 11$ & $\begin{array}{l}\text { SME Profits comparing } \\
\text { with the collaborative } \\
\text { partner within the NHN } \\
\text { Trust } \\
\text { Uncertainty } \\
\end{array}$ & $\begin{array}{r}\text { Share Profits and } \\
\text { Costs }\end{array}$ & $\mathrm{T}$ \\
\hline & $\begin{array}{l}\text { Partners relationships } \\
\text { through collaborative } \\
\text { mechanisms }\end{array}$ & $Q: 12$ & Collaboration Mechanisms & $\begin{array}{r}\text { Collaboration } \\
\text { Mechanisms Design }\end{array}$ & $\mathrm{S} / \mathrm{T}$ \\
\hline & $\begin{array}{l}\text { Order Promising } \\
\text { Process }\end{array}$ & $Q: 13$ & $\begin{array}{l}\text { Orders's } \\
\text { Management }\end{array}$ & OPP & $\mathrm{O}$ \\
\hline & Information & $Q: 14$ & $\begin{array}{l}\text { Willingness for information } \\
\text { exchanging }\end{array}$ & Information Exchange & \\
\hline
\end{tabular}


Table 2. cont. Degree of Adaptation to identify SMEs needs based on 4-Dimensional Analysis (S: Strategic, T: Tactical, O: Operational)

\begin{tabular}{|c|c|c|c|c|c|}
\hline & $\begin{array}{l}\text { Collaborative } \\
\text { NHN }\end{array}$ & $\begin{array}{c}\text { Adaptation } \\
\text { Degree }\end{array}$ & SME & $\begin{array}{r}\text { PROBLEM TO } \\
\text { TACKLE }\end{array}$ & LEVEL \\
\hline \multirow{8}{*}{ 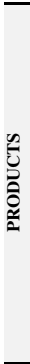 } & Product & $Q: 15$ & $\begin{array}{l}\text { Product } \\
\text { Importance for the NHN }\end{array}$ & Product Design & S \\
\hline & Collaborative Forecast & $Q: 16$ & Forecast System & $\begin{array}{r}\text { Collaborative } \\
\text { Forecast }\end{array}$ & $\mathrm{T}$ \\
\hline & $\begin{array}{l}\text { Collaborative } \\
\text { Planning }\end{array}$ & $Q: 17$ & SME Planning & $\begin{array}{r}\text { Operation } \\
\text { Planning }\end{array}$ & $\mathrm{T}$ \\
\hline & $\begin{array}{l}\text { Collaborative } \\
\text { Replenishment }\end{array}$ & $Q: 18$ & $\begin{array}{l}\text { SME } \\
\text { Replenishment } \\
\text { Order } \\
\text { Management } \\
\end{array}$ & Replenishment & $\mathrm{T}$ \\
\hline & CPFR & $Q: 19$ & $\begin{array}{l}\text { Willingness for information } \\
\text { exchanging }\end{array}$ & $\begin{array}{r}\text { Information } \\
\text { Management }\end{array}$ & $\mathrm{T}$ \\
\hline & \multirow{2}{*}{$\begin{array}{l}\text { Collaborative } \\
\text { Scheduling }\end{array}$} & \multirow[t]{2}{*}{$Q: 20$} & $\begin{array}{l}\text { Production } \\
\text { Scheduling }\end{array}$ & \multirow[t]{2}{*}{ Scheduling } & \multirow[t]{2}{*}{$\mathrm{O}$} \\
\hline & & & Production Lines & & \\
\hline & $\begin{array}{l}\text { Inventory } \\
\text { Management }\end{array}$ & $Q: 21$ & $\begin{array}{l}\text { Product Stocking } \\
\text { Lotsizing }\end{array}$ & $\begin{array}{r}\text { Inventory } \\
\text { Management }\end{array}$ & $\mathrm{O}$ \\
\hline
\end{tabular}

$\left(Q_{x}:\right.$ question developed in Table 3$)$

Being from 0 to 3 degrees of adaptation implies that the SMEs capabilities and resources do not encourage the requirements needed to participate in a collaborative NHN for establishing internationalisation processes. Besides, for those problems whose degree of adequacy is between 0 and 5 SMEs should seek on solutions to favour a higher adequacy (between 6 and 10).

This classification allows networked partners know what their weaknesses are and where they must improve to efficiently belong to a collaborative NHN based on decentralised and internationalised decisions.

Table 3. Questionnaire for identifying SMEs Needs based on 4-Dimensional Analysis

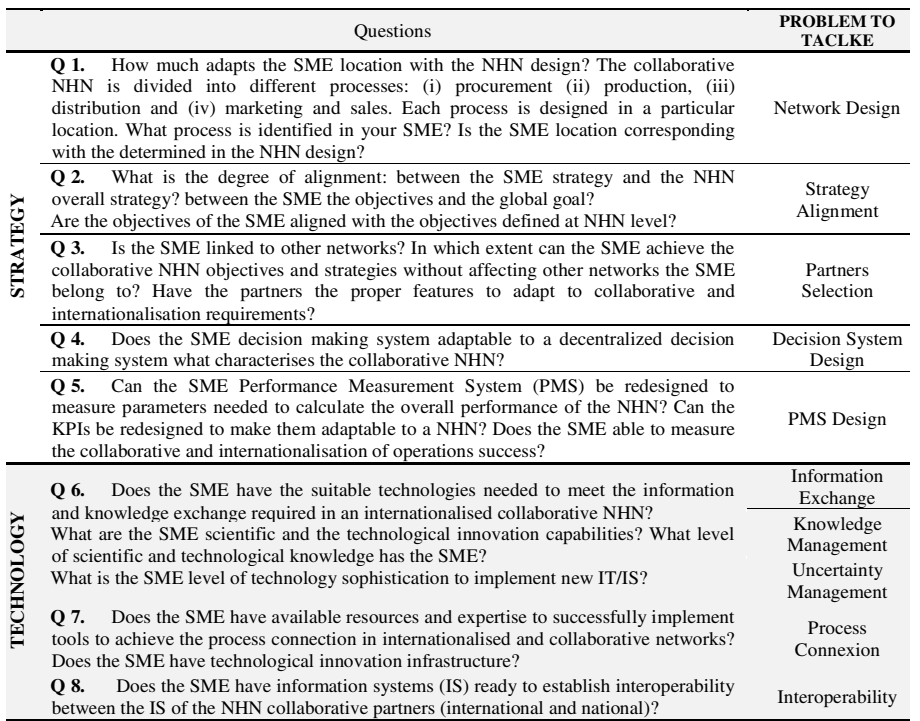


Table 3. cont. Questionnaire for identifying SMEs Needs based on 4-Dimensional Analysis

\begin{tabular}{|c|c|c|}
\hline & Questions & $\begin{array}{l}\text { PROBLEM TO } \\
\text { TACLKE }\end{array}$ \\
\hline \multirow{6}{*}{ 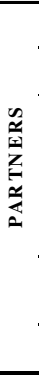 } & $\begin{array}{l}\text { Q 9. Is the SME strategy aligned with the strategies of the NHN partners? } \\
\text { Is there a threat of vertical integration for the SME's partners? }\end{array}$ & $\begin{array}{l}\text { Partners } \\
\text { Selection } \\
\end{array}$ \\
\hline & $\begin{array}{l}\text { Q 10. Does the SME have defined negotiation protocols with other partners? Does the } \\
\text { SME have capacity, bargaining power and tools to negotiate? }\end{array}$ & $\begin{array}{c}\text { Negotiation } \\
\text { Contracts }\end{array}$ \\
\hline & $\begin{array}{l}\text { Q 11. Is the SME willing to equally share profits among the NHN collaborative } \\
\text { partners? Does the SME trust to share profits? What are the SME profits in relation to } \\
\text { the collaborative partners? How are the profits measured in the SME? Is the SME } \\
\text { measurement system consistent with the NHN profits measurement? }\end{array}$ & $\begin{array}{l}\text { Share Costs And } \\
\text { Profits }\end{array}$ \\
\hline & $\begin{array}{l}\text { Q 12. Does the SME establish collaborative mechanisms? Does the SME have know } \\
\text { how to use collaborative mechanisms to establish closer relationships among } \\
\text { internationalised NHN members? }\end{array}$ & $\begin{array}{l}\text { Collaboration } \\
\text { Mechanisms }\end{array}$ \\
\hline & $\begin{array}{l}\text { Q 13. How is done the Order Promising Process (OPP) within the SME? Can the SME } \\
\text { OPP be connected with inventory and production capacities of other NHN partners? } \\
\text { The OPP within the SME, could be connected with other NHN partners? }\end{array}$ & $\begin{array}{l}\text { Order Promising } \\
\text { Process }\end{array}$ \\
\hline & $\begin{array}{l}\text { Q14. Is the SME willing to share information amongst NHN collaborative partners? } \\
\text { Does the SME distinguish private from public information? }\end{array}$ & $\begin{array}{l}\text { Information } \\
\text { Exchange }\end{array}$ \\
\hline \multirow{7}{*}{$\begin{array}{l}n \\
0 \\
0 \\
0 \\
0 \\
\approx \\
2\end{array}$} & $\begin{array}{l}\text { Q 15. How important is, for the internationalised collaborative NHN, the product } \\
\text { manufactured by the SME? }\end{array}$ & Product Design \\
\hline & $\begin{array}{l}\text { Q 16. Does the SME trust enough to share or accept the downstream partner's forecast } \\
\text { data? Does the SME works with POS data? Which security system to exchange } \\
\text { information uses the SME? }\end{array}$ & $\begin{array}{l}\text { Collaborative } \\
\text { Forecast }\end{array}$ \\
\hline & $\begin{array}{l}\text { Q 17. Does the SME have a collaborative planning system? } \\
\text { What sort of planning system uses the SME? Can be adapted to the collaborative system } \\
\text { within the NHN? Is the SME willing to share data plan information with other members } \\
\text { of the collaborative NHN? }\end{array}$ & $\begin{array}{c}\text { Operation } \\
\text { Planning }\end{array}$ \\
\hline & $\begin{array}{l}\text { Q 18. Does the SME use a replenishment system managed by the supplier? Does the } \\
\text { SME perform a collaborative replenishment process amongst national and international } \\
\text { partners? }\end{array}$ & Replenishment \\
\hline & $\begin{array}{l}\text { Q 19. Does the SME use a collaborative planning, forecast and replenishment system? } \\
\text { Is the SME willing to jointly manage the information with NHN partners? }\end{array}$ & $\begin{array}{l}\text { Information } \\
\text { Management }\end{array}$ \\
\hline & $\begin{array}{l}\text { Q 20. Does the SME use a distributed scheduling? Is the scheduling processes } \\
\text { collaboratively done a mong NHN partners? What SME production lines are included in } \\
\text { the NHN? }\end{array}$ & Scheduling \\
\hline & $\begin{array}{l}\text { Q 21. How is the SME inventory management performed? Does the supplier manage } \\
\text { the SME inventory? Does the SME have any inventory management system? Is the } \\
\text { SME willing to jointly manage the inventory within NHN partners? }\end{array}$ & $\begin{array}{c}\text { Inventory } \\
\text { Management }\end{array}$ \\
\hline
\end{tabular}

\section{Conclusions}

In this paper, a methodology to identify the weaknesses of SMEs arising from participating in a NHN is provided. The methodology assesses the current state of SMEs in order to be known by themselves and by their networked partners. The SMEs needs identification provides an important improvement in order to establish decentralised decisions within networks characterised by the internationalisation of operations.

Next steps regarding the methodology are focused on the implementation of a questionnaire to obtain a representative sample of SMEs, in order to identify the major gaps affecting the collaborative and internationalised processes. In this context the main objectives to carry out are (i) to apply the methodology through a questionnaire in order to determine what are the problems and needs encountered in SMEs when establish collaborative processes when they decide to internationalise their operations and (ii) to provide researchers a global vision of the SMEs current situation in order to give an insight to start a series of solution proposals to enable the SMEs participation in collaborative and internationalised NHN. The distributed questionnaire will allow the subsequent search of solutions to reduce the SMEs weaknesses. Therefore, through the provided paper experts should be able to assess the SMEs current capabilities that will define their preparation, readiness and potential benefits to face a membership in a NHN based in internationalisation of operations. Finally, upcoming work is leaded solve the encountered SMEs needs to establish collaborative 
relationships characterized by decentralised decision making; and propose the best solution to overcome the problems within the international, collaborative and decentralised context.

\section{References}

1. Camarinha-Matos, L., Afsarmanesh, H., Galeano, N., Molina, A.: Collaborative networked organisations - Concepts and practice in manufacturing enterprises. Computers \& Industrial Engineering 57(1), 46-60 (2008)

2. Corti, D., Egaña, M.M., Errasti, A.: Challenges for off-shored operations: findings from a comparative multi-case study analysis of Italian and Spanish companies. In: Proceedings 16th Annual EurOMA Conference (2009)

3. Mediavilla, M., Errasti, A., Domingo, R.: Framework for assessing the current strategic factory role and deploying an upgrading roadmap. An empirical study within a global operations network. Dirección y Organización 46, 5-15 (2012)

4. Martínez, S., Errasti, A., Santos, J., Mediavilla, M.: Framework for improving the design and configuration process of a global production and logistic network. In: Emmanouilidis, C., Taishch, M., Kiritsis, D. (eds.) APMS 2012, Part II. IFIP AICT, vol. 398, pp. 471-478. Springer, Heidelberg (2013)

5. Andrés, B., Poler, R.: Análisis de los Procesos Colaborativos en Redes de Empresas NoJerárquicas. In: Ros, L., Fuente, V., Hontoria, E., Soler, D., Morales, C., Bogataj, M. (eds.) Ingeniería Industrial: Redes Innovadoras. XV Congreso de Ingeniería de Organización, CIO 2011 Libro de Actas, Cartagena, Spain, September 7-9, pp. 369-373 (2011)

6. Andrés, B., Poler, R.: Relevant Problems in Collaborative Processes of Non-Hierarchical Manufacturing Networks. In: Prado, J.C., García, J., Comesaña, J.A., Fernández, A.J. (eds.) 6th International Conference on Industrial Engineering and Industrial Management, Vigo, Spain, July 18-20, pp. 90-97 (2012)

7. Alfaro, J.J., Rodríguez, R., Ortiz, A., Verdecho, M.J.: An information architecture for a performance management framework by collaborating SMEs. Computers in Industry 61(7), 676-685 (2010)

8. Ferdows, K.: Making the most of foreign factories. Harvard Business Review, 73-88 (March-April 1997)

9. Flaherty, T.: Coordinating International Manufacturing and Technology. In: Porter, M. (ed.). Harvard Business School Press (1986)

10. McGee, J., Thomas, H., Wilson, D.: Strategy: Analysis and Practice. McGraw-Hill, New York (2005) 